\title{
Preface to the 2005 Edition
}

The first edition of Epic Encounters was published in September 2001. That coincidence of timing meant that it was inevitably read in light of the painful questions raised by the terrorist attacks on New York and Washington. The book's concerns-with U.S. cultural representations of the Middle East, U.S. foreign policy, the role of religion in politics, and the politics of race, among others-brought it into a broad conversation in the United States and elsewhere about history, culture, and September 11. I believe the particular contribution of this study was its analysis of the ways in which popular culture and foreign policy have intersected over the last fifty years, as diverse groups of Americans have fashioned for themselves a series of political and cultural understandings of the Middle East. Popular culture, public debates, the news media, and various social and religious movements forged a web of meanings that have often facilitated-and sometimes challenged - the expansion of U.S. power in the Middle East, even as they worked to construct a self-image for Americans of themselves as citizens of a benevolent world power.

There were, of course, many questions that the first edition of Epic Encounters did not address. It did not discuss Osama bin Laden, although he had been behind several attacks on U.S. installations in the 1990s. Nor did it analyze the history of U.S. involvement in Central Asia, which was outside its geographic focus. The book also could not answer, except indirectly, the question "Why do they hate us?" since this study was, and remains, an Americanist account of the construction of U.S. interests. I consider those interests to be both political and cultural, or rather, to be the product of the intersection of the two, which are intimately and inevitably intertwined. As I hope the book also shows, the construction of U.S. "interests" is not an uncontested process. There has never been a univocal 
"American" response to the Middle East. Even when it seems as if one set of cultural norms or political voices dominates the landscape, there are critical alternatives, from both the right and the left, from different racial groups, and from a variety of religious perspectives.

When the first edition was published, scholarship on culture and U.S. foreign policy - on the culture of American power-was still in its infancy. Edward Said's Orientalism had been the touchstone for those of us who hoped to bring his subtle attention to the cultural politics of European empire to bear on U.S. history. Several generations of scholars and political activists around the world are in Said's debt, and with his death in the fall of 2003, we lost an intellectual voice of unprecedented integrity and insight. In the wake of Orientalism, several groundbreaking books within U.S. and postcolonial studies (by Ali Behdad, Amy Kaplan, Lisa Lowe, Emily Rosenberg, Gail Bederman, and others) appeared, but each still needed to make the argument, sometimes laboriously, that cultural products mattered to understanding the U.S. role in the world, and that cultural analysis could make a contribution to that understanding.

Since the mid-1990s, however, scholars from several different disciplines have heeded Amy Kaplan's call, which I discuss in the introduction to this book, to move beyond the traditional domestic focus of American Studies and the limits of political history within foreign policy studies, and to bring the cultural analysis of empire into the heart of U.S. studies. This more recent work includes fine books from within the field of American Studies by Laura Briggs, Matthew Jacobson, Christina Klein, Mary Renda, Shelley Streeby, and Mari Yoshihara, among others. At the same time, scholars trained in the history of U.S. foreign policy, including Christopher Jespersen, Kristin Hoganson, Michael Hunt, Akira Iriye, Andrew Rotter, and Penny von Eschen, to name only a few, have begun to turn their attention to the role of cultural images and popular culture in diplomatic history. These analyses have argued in different ways that the boundaries between the national and international spheres, between culture and politics, between state actors and transnational flows, and between cultural analysis and policy history are far more porous than previous academic divisions of labor have recognized.

In addition, an increased consciousness of the realities of globalization has provided the occasion for work that crosses the boundaries of nationally based studies to undertake genuinely transnational analyses. Although Epic Encounters takes U.S. culture and policy as its topic, it benefits enormously from work that insists that the boundaries of thought, culture, and identity do not stop at national borders. For me, the influence of the work 
of Paul Gilroy is preeminent here, but many others have reframed crucial questions about the borders of scholarly analysis, including Anthony Appadurai, Michael Denning, George Lipsitz, Mary Layoun, and Michael Hardt and Antonio Negri.

This updated edition of Epic Encounters includes a new chapter, "9/11 and After: Snapshots on the Road to Empire," which explores the complex weave of cultural and political narratives in the U.S. public sphere since September 11. My hope is that this chapter will show that the process of making meanings of the events of September 11 has required cultural work, and that no one response was inevitable, even as a range of political actors and cultural institutions converged in the process of making the war on terrorism into "common sense."

Any attempt to reckon with the world after September 11 is necessarily constrained by the force of current events: we are looking backward at something that is still rushing ahead. As a college teacher, however, I am cognizant of the fact that, by 2006, most of my freshmen students will have been thirteen years old on the day that begins this new chapter. My goal is to write a history that will help them better understand what are likely to be the defining political events of their lives.

I cannot claim that the analysis in the new chapter has the full benefit of scholarly distance, to the degree that such a thing can ever be achieved. While I have been as honest and as careful as I can in my assessment of what has happened in the few short years since the terrorist attacks on New York and Washington, I am aware that any study of recent and deeply traumatic events like terrorism and war will be profoundly marked by those wounds.

As this goes to press, struggles over the meaning of the memory of September 11-and the possibility of forgetting the suffering of othersare both very much alive. The third anniversary of September 11 has just been commemorated. Where the twin towers once stood in New York, the memorial to the victims is under construction. In Afghanistan, people have been freed from the repressive rule of the Taliban only to find themselves, everywhere outside of Kabul, ruled by local leaders only marginally less strict in their interpretations of Islam, and even less able to provide security to the populace, than the former government.

In Iraq, the United States has handed over power to an Iraqi government that is only officially sovereign. The U.S. occupation has not ended, and is not likely to end for some time. Violence has continued to escalate, and there and elsewhere in the world, terrorism remains a threat and a reality. Throughout the Middle East, anti-Americanism is at an all-time high, 
among even those people who might once have been at least ambivalent about U.S. intentions and actions. With the failures in Iraq, the question of what role the United States will play in the Middle East and elsewhere is uncertain. Certainly the ambitious and deadly dreams of the Bush administration have now been exposed as a costly imperial gamble. What price we will all pay is yet not fully reckoned.

Washington, D.C.

November 2004 